\title{
PENERAPAN PENDIDIKAN AKHLAK IBU RUMAH TANGGA DI DESA PERBATASAN \\ ( STUDI FENOMENOLOGIS DI DESA PERBATASAM SUMATERA UTARA DAN SUMATERA BARAT )
}

\author{
Syafnan $^{1}$ \\ email : syafnanlubis6@gmail.com
}

\begin{abstract}
ABSTRAK
Penelitian ini bertujuan untuk mengungkapkan: penerapan pendidikan akhlak ibu rumah tangga di desa multi etnis yang, daerah perbatasan Propinsi, baik dalam acara duka cita, suka cita, dan kegiatan pemerintah desa. Penerapan pendidikan akhlak Ibu rumah tangga adalah perilaku menonjol yang diperlihatkan kepada orang lain pada kegiatan kemasyarakatan. Metodologi penelitian adalah kualitatif model fenomenologis, dengan sumber data kunci adalah 15 orang ibu rumah tangga yang berusia 20 sampai 47 tahun, instrument yang dipakai adalah pedoman wawancara terstruktur dan observasi, serta mengolah data yang dimulai dari pengumpulan, validasi, analisa, triangulasi, dan membuat kesimpulan.Hasil penelitian: 1. Ibu rumah tangga selalu waspada dalam dalam penggunaan waktu keseharian untuk berada di tempat musibah, berpakaian rapi tanpa membuka aurat, dan memberi sumbangan; 2. Mengikuti program desa terutama kegiatan upacara hari besar kebangsaan, dan kegiatan pelatihan desa di bidang kerajianan tangan kreatif; 3.Membina akhlak anak mereka dengan mengandalkan Taman Pendidikan Alqur'an
\end{abstract}

\section{Katan Kunci: Pendidikan Akhlak dan Ibu Rumah Tangga}

\begin{abstract}
This study aims to reveal: morals education implementation of housewives in multi-ethnic villages, provincial border areas, both in the event of grief, joy, and activities of the village government. Implementation morality of the intended housewife is the prominent behavior that is shown to others in social activities. The research methodology is a qualitative phenomenological model, with key data sources are 15 housewives aged 20 to 47 years, the instruments used are guidelines for structured interviews and observations, and data processing that starts from collecting, validating, analyzing, triangulating, and making conclusion.Research results: 1 . Housewives are always vigilant in the use of daily time to be in a place of disaster, dress neatly without opening aurat, and giving donations; 2 . Participating in the village program, especially national ceremonies, and village training activities in the field of creative handicrafts; 4. Developing the morals of their children by relying on the Alquran Education Park
\end{abstract}

Keywords: Housewife and Morals education

\footnotetext{
${ }^{1}$ Dosen Institut Agama Islam Negeri Padangsidimpuan
} 


\section{PENDAHULUAN}

a. Latar Belakang Masalah

Akhlak adalah sifat yang tertanam dalam jiwa, dan padanya timbul perbuatan yang mudah, tidak jarang didahului dengan pertimbangan pikiran yang teramati dalam bentuk budi pekerti, atau perangai, atau disebut juga perilaku manusia sehari-harinya. Akhlak merupakan suatu kesusilaan atau sopan santun yang menggambarkan sifat bathin manusia, gambaran bentuk lahiriah manusia yang terpancar pada raut wajah, dan gerak anggota tubuh, atau juga seluruh tubuh. Dalam kamus Al-Munjid akhlak itu diartikan sebagai ilmu tata krama, ilmu yang berusaha mengenal tinggah laku manusia kemudian memberi nilai kepada perbuatan baik atau buruk sesuai dengan norma dan tata susila. ${ }^{2}$

Akhlak dari segi fungsinya dapat dipahami sebagai suatu alat untuk menjalin hubungan baik antara manusia dengan Tuhannya, hubungan antar sesamamanusia, manusia kepada hewan, manusia kepada tumbuh-tumbuhan dan kepada benda mati. Akhlak manusia kepada Allah dapat tercermin dari kepatuhan dan ketaatan seseorang dalam menjalankan perintah, menjauhi larangan yang ditetapkan oleh Allah dalam Al-Quran dan melalui suri tauladan Rasulullah. Akhlak yang telah mapan merupakan modal utama bagi manusia dalam membina hubungan yang komunikatif, harmonis dan elegan.Dalam hadist AlBukhari dinyatakan, diantaranya sebagai berikut:

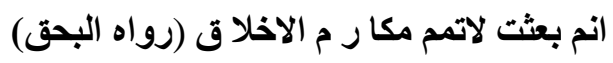

"sesungguhnya aku diutus untuk menyempurnakan akhlak".

Arti hadist ini dapat dipahami bahwa pembentukan akhlak manusia merupakan salah satu misi kenabian yang mesti dilestarikan oleh setiap muslim.Penerapan pendidikan akhlak adalah tugas utama orangtua, dan pendidik yang bertanggung jawab untuk memelihara dan mengasuh generasi ${ }^{3}$

Penerapan pendidikan akhlak harus melekat pada setiap ibu rumah tangga karena sehari harinya harus mendidik anak mereka, namun kenyataannya Ibu rumah tangga yang ada di desa desa perbatasan masih kurang bagus, sekitar $50 \%$ belum begitu menjaga akhlak. Hal ini terlihat bahwa berpakaianibu-ibu belum mencerminkan syariah Islam, penggunaan waktu yang tidak terarah, dan pendidikan akhlak anak cendrung diserahkan

\footnotetext{
${ }^{2}$ M. Yatim Abdullah, Studi Akhlak Dalam Perspektif Al-Qur'an, (Jakarta: Amzah, 2007), h. 2-3.

${ }^{3}$ Hamdani Ihsan dkk, Filsafat Pendidikan Islam, (Bandung: Pustaka Setia, 2007), h. 240.
} 
pada Pendidikan Agama di Sore hari. Situasi seperti ini yang mendorong peneliti untuk melihat kenyataan yang sebenarnya.

\section{b. Rumusan Masalah}

1. Bagaimana pendidikan akhlak ibu rumah tangga dalam merespon kegiatan duka cita di desa PerbatasanSumatera Utara dan Sumatera Barat?.

2. Bagaimana pendidikan akhlak ibu rumah tangga dalam merespon kegiatan suka cita di desa PerbatasanSumatera Utara dan Sumatera Barat?.

3. Bagaimana kegiatan ibu rumah tangga dalam mengikuti kegiatan Pemerintah Desa di desa PerbatasanSumatera Utara dan Sumatera Barat?.

4. Apa aktivitas ibu rumah tangga dalam mengikuti program pendidikanakhlak di desa PerbatasanSumatera Utara dan Sumatera Barat?.

\section{TINJAUAN TEORITIS}

a. Pengertian Akhlak

Secara bahasa (etimologi) perkataan akhlak adalah bentuk jamak dari khuluq (khuluqun) yang berarti budi pekerti, perangai, tingkah laku atau tabiat. Akhlak itu disamakan dengan kesusilaan, sopan santun.Khuluq merupakan gambaran sifat batin manusia, gambaran bentuk lahiriah manusia, seperti raut wajah dan gerak anggota badan dan seluruh tubuh.Dalam bahasa Yunani pengertian khuluq ini disamakan dengan ethichos atau ethos, artinya adab kebiasaan, perasaan batin, kecendrungan hati untuk melakukan perbuatan.Ethicos kemudian berubah menjadi etika. ${ }^{4}$

Berdasarkan pengertian di atas dapat dipahami bahwa akhlak adalah kebiasaan, perangai, tingkah laku yang baik pada diri seseorang yang tercermin dalam kehidupannya sehari-hari. Dalam al-Qur'an terdapat beberapa ayat yang memiliki kata khuluq, di antaranya adalah al-Qur'an surat al-Qalam ayat 4 sebagai berikut:

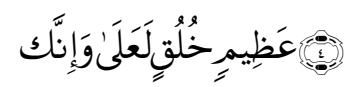

Artinya: Dan Sesungguhnya kamu benar-benar berbudi pekerti yang agung. ${ }^{5}$

Dalam ayat di atas kata khuluq diartikan sebagai budi pekerti.Selanjutnya dalam surat al-Syu'ara ayat 137 Allah SWT berfirman:

${ }^{4}$ M.Yatim Abdullah, Studi Akhlak dalam Perspektif Al-Qur'an, (Jakarta: Amzah, 2007), h. 2-3.

${ }^{5}$ Departemen Agama RI,al-Qur'an dan Terjemahannya, (Bandung: Diponegoro, 2007), h. 564. 


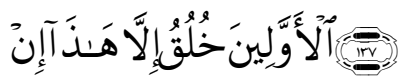

Artinya: Ini tidak lain hanyalah adat kebiasaan orang dahulu. ${ }^{6}$ Pada ayat di atas kata khuluq diartikan sebagai adat kebiasaan. Jadi akhlak adalah adat kebiasaan, adat istiadat atau segala sesuatu yang sudah menjadi tabiat.

Sumber yang mengilhami pendidikan akhlak adalah:

1. Al-Qur'an

Al-Qur'an dari segi etimologi berasal dari kata "qoroa" yaqrou, qur'anan, artinya bacaan.Dapat juga diartikan dengan arti isim maful, maqrou, yang berarti dibaca.Para ahli agama Islam memberikan pengertian bahwa al-Qur'an adalah wahyu Allah yang diturunkan kepada Rasulullah Muhammad SAW, melalui malaikat Jibril yang disampaikan kepada kita umatnya secara mutawatir, ibadat membacanya dan menjadi kafir bagi orang yang mengingkarinya. ${ }^{7}$

Di dalam al-Qur'an terkandung dua ajaran pokok yang dapat dikembangkan untuk seluruh aspek kehidupan manusia melalui ijtihad yang terdiri dari dua prinsip besar, yaitu yang berhubungan dengan masalah keimanan yang disebut aqidah dan yang berhubungan dengan amal yang disebut syari'ah. ${ }^{8}$

2. As-Sunnah

Kedudukan As-sunnah sebagai sumber ajaran Islam selain didasarkan pada keterangan ayat-ayat al-Qur'an dan Hadist yang didasarkan kepada pendapat kepada kesepakatan para sahabat, yakni seluruh sahabat sepakat untuk menetapkan tentang wajib mengikuti Hadist baik pada masa Rasulullah masih hidup maupun setelah beliau wafat. ${ }^{9}$

As-sunnah adalah perkataan, perbuatan ataupun pengakuan Rasulullah SAW. Sementara itu kebanyakan para ulama ahli hadis mengartikan as-sunnah, al-Hadis, al-Khabar, al-Atsar sama saja, yaitu segala sesuatu yang disandarkan kepada Nabi Muhammad SAW. Baik dalam bentuk ucapan, perbuatan maupun ketetapan.Pengertian ini didasarkan kepada pandangan mereka terhadap Nabi sebagai suri teladan yang baik bagi manusia.

\footnotetext{
${ }^{6}$ Ibid, h. 373.

${ }^{7}$ Rusman Hasibuan, Inilah Islam, (Padangsidimpuan: Pencetakan Ilmiyah, 2000),h.36.

${ }^{8}$ Zakiah Darajat, dkk, Ilmu Pendidikan Islam (Jakarta: PT Bumi Aksara, 2008), h. 19.

${ }^{9}$ Abuddin Nata, Metodologi Studi Islam, (Jakarta: PT. Raja Grapindo Persada, 2002), h.72.
} 


\section{b. Ibu Rumah Tangga}

Akhlak ibu rumah tangga adalah yang menempatkan kepribadian sebagai seorang istri, merasakan tanggung jawab bersama baik suami maupun istri (saling mengingatkan dan jangan selalu menuntut), selalu bermusyawarah (berdialog) dengan komunikasi dengan baik dan menjadikan pasangan pusat perhatian.

Ciri-ciri ibu rumah tangga yang baik antara lain memiliki sikap rela berkorban tanpa pamrih, memelihara hubungan yang baik dengan suami, patuh terhadap suami, menjaga kebersihan rumah, memiliki managemen waktu yang baik, menjaga rahasia keluarga. ${ }^{10}$

\section{c. Pendidikan Akhlak}

Menurut al- Al-Abrasyi, pendidikan akhlak adalah mempersiapkan individu atau pribadi agar bisa : menghadapi,kehidupan ini secara sempurna, hidup bahagia, cinta tanah air, kuat jasmani, sempurna akhlaknya, teratur dalam berpikir, berperasaan lembut, mahir dalam bidang ilmu, saling membantu dengan sesamanya, memperindah ungkapan pena dan lisannya serta membaguskan amal perbuatannya. ${ }^{11}$

\section{d. Penelitian Terdahulu}

Melalui penelitian terdahulu, maka penulis mengamati penelitian pembahasan yang sudah ada sebagai berikut:

1. Penelitian Erwin Yudi Prahara, dengan judul"Konsep Pendidikan Akhlak Menurut AlGhazali”. Penelitian ini dilaksanakan pada tahun 2005, oleh Dosen STAIN Ponegoro. Hasil penelitian ini menggambarkan bahwa akhlak itu dapat dikatakan ibarat dari keadaan jiwa dan bentuknya bersifat batiniah, sebagaimana bentuk kebagusan lahiriah secara mutlak tidak sempurna dengan bagusnya dua mata saja, tidak dengan hidung yang bagus, mulut atau pipi tetapi harus bagus semua. Sepertinya kebagusan dhahiriah itu maka demikian pula pada batiniah harus sempurna supaya tercapai kebagusan akhlak. ${ }^{12}$

\footnotetext{
${ }^{10}$ Kartono,“cara untuk menjadi ibu rumah tangga yang baik”https://id.m.wikihow.com, , di akses pada jam 09.00, tanggal, 13 Mei 2018.

${ }^{11}$ Abd. Rachman Assegaf, Aliran Pemikiran Pendidikan Islam : Hadharah Keilmuan Tokoh Klasik Sampai Modern (Jakarta: Rajawali Pers, 2013), hlm. 198.

${ }^{12}$ Erwin Yudi Prahara, Jurnal Kependidikan dan Kemasyarakat'Konsep Akhlak Menurut Alghazali”, dalam Jurnal Cendikiawan, Volume.3 No. 1, Januari 2005, hlm. 91.
} 


\section{METODOLOGI PENELITIAN}

\section{Tempat}

Penelitian ini dilakukan di desa desa perbatasan Provinsi Sumatera Utara dan Sumatera Barat, lokasi dua etnis Budaya namun masih menganut agama Islam yang taat. Salah satunya di Bangun Saroha KecamatanRanto Baek Kabupaten Mandailing Natal Provinsi Sumatera Utara, dan desa Silaping kec. Ranah Batahan Pasaman Barat.

\section{Waktu}

Penelitian ini dilaksanakanpada bulan Sept. 2017 sampai akhir 2018.

\section{JenisPenelitian}

Penelitian ini menggunakan pendekatan kualitatif model fenomenologi ${ }^{13}$ Penelitian ini menggambarkan bagaimana pendidikan akhlak ibu rumah tangga di desa Bangun Saroha dan Silaping. Penelitian ini tidak menggunakan hipotesis melainkan hanya mendeskripsikan informasi fenomena yang diamati apa adanya sesuai dengan hasil penelitian. ${ }^{14}$

\section{Sumber Data}

Sumber data dalam penelitian ini terbagi kepada dua, yaitu:

Sumber data primer adalah ibu rumah tangga dengan jumlah 15 orang yang berusia 20 sampai 47 tahun di desa Bangun Saroha dan Silaping. Jumlah ibu rumah tangga yang diteliti sebanyak 15orang ibu rumah tangga yang masih memiliki pasangan seperti digambarkan pada tabel 1 di bawah ini.

Tabel 1.

Data Ibu Rumah Tangga di Bangun Saroha - Silaping

\begin{tabular}{|l|l|l|l|}
\hline No & \multicolumn{1}{|c|}{ Nama } & \multicolumn{1}{c|}{ Peran } & Jumlah \\
\hline 1 & Irawani & Ibu Rumah Tangga & 1 \\
\hline 2 & Marlina & Ibu Rumah Tangga & 1 \\
\hline 3 & Roslina & Ibu Rumah Tangga & 1 \\
\hline 4 & Samsianar & Ibu Rumah Tangga & 1 \\
\hline 5 & Musdalipah & Ibu Rumah Tangga & 1 \\
\hline 6 & Ratna & Ibu Rumah Tangga & 1 \\
\hline 7 & Munawaroh & Ibu Rumah Tangga & 1 \\
\hline 8 & Ani & Ibu Rumah Tangga & 1 \\
\hline 9 & Zuaraida & Ibu Rumah Tangga & 1 \\
\hline 10 & Dahliana & Ibu Rumah Tangga & 1 \\
\hline 11 & Mariana & Ibu Rumah Tangga & 1 \\
\hline
\end{tabular}

${ }^{13}$ LexyJ.Moleong, MetodologiPenelitianKualitatif,(Bandung: Rosdakarya, 2000), h. 5.

${ }^{14}$ Sukardi, MetodologiPenelitianPendidikanKompetensidanPrakteknya, (Jakarta: BumiAksara, 2003), h. 157. 


\begin{tabular}{|l|l|l|l|}
\hline 12 & Aisyah & Ibu Rumah Tangga & 1 \\
\hline 13 & Darisma & Ibu Rumah Tangga & 1 \\
\hline 14 & Enismaniar & Ibu Rumah Tangga & 1 \\
\hline 15 & Dewi & Ibu Rumah Tangga & 1 \\
\hline
\end{tabular}

Sumber Data: Kantor Kepala Desa Kecamatan

Adapun data skunder, yaitu pengambilan data melalui tangan kedua. Adapun sumber data skunder dalam penelitian adalah kepala desa, tokoh agama dan anak di desa Bangun Saroha - Silaping, dapat dilihat pada tabel 2 di bawah ini:

Tabel 2.

Data Kepala Desa, Tokoh Agama, Anak Ibu Rumah Tangga di desaBangun Saroha - Silaping

\begin{tabular}{|l|l|l|}
\hline No & \multicolumn{1}{|c|}{ Nama } & \multicolumn{1}{c|}{ Jabatan } \\
\hline 1 & Samhar Lubis dan Salamat & Kepala Desa \\
\hline 2 & Muhammad jafar dan S.Lubis & Tokoh Agama \\
\hline 3 & Sari dan Utami & Anak \\
\hline 4 & Evita Sari & Anak \\
\hline 5 & Nur Hidayah dan Najm & Anak dan Ibu Rumah Tangga \\
\hline 6 & Novita & Anak \\
\hline
\end{tabular}

Sumber Data: Kepala Desa Kecamatan

\section{Instrumen Pengumpulan Data}

a. Wawancara

Adapun pokok-pokok yang diwawancarai adalah:

Akhlak ibu rumah tangga di dalam rumah, Bagaimana akhlak ibu rumah tangga di luar rumah pada kegiatan suka cita dan kegiatan suka ria, apa kegiatan ibu rumah tangga dalam mengikuti program pemerintahan desa , serta cara ibu membina anak-anak melalui pendidikan akhlak.

b. Observasi

Observasi dilakukan bila mana data dari hasil wawancara belum terasa lengkap.

\section{Teknik Analisis Data}

Adapun hal-hal yang harusdilakukanpenelitianuntukmendapatkan data yang akurat adalah sebagai berikut: Reduksi data, Penyajian data, himpun dan ferivikasi data, dan pelaporan.

\section{Teknik Menjamin Keabsahan Data}

Adapun hal-hal yang harus dilakukan peneliti untuk mendapatkan data yang akurat adalah sebagai berikut: 
a. Ketekunan pengamatan,bertujuan untuk menemukan ciri-ciri dan unsur-unsur dalam situasi yang relevan.

b. Triangulasi, yaitu suatu pendekatan analisis data dengan menguji informasi melalui metode yang berbeda, dari kelompok sumber data berbeda,namun dalam karakter yang hamper sama.

\section{HASIL PENELITIAN}

\section{A. Temuan Umum}

\section{Sejarah Berdirinya Desa}

a. Desa Bangun Saroha berdiri pada tahun 1922. Asal mula berdirinya desa Bangun Saroha sebenarnya disebabkan karena perpindahan dari desa Kotanopan Sumatera Utara. Terjadinya seperti ini karena mencari lahan sangat luas. ${ }^{15}$

b. Desa Silaping, berdiri sekitar 1890 yang ditokohi oleh Sutan Marangkati Lubis dan anaknya Raja Mas, mereka mereka ini adalah berasal dari desa Muara Mais Pastab Kotanopan juga, dan punya karakter budaya yang sama dengan Bangun Saroha

c. Sarana Penduduk Sarana penduduk merupakan suatu penunjang maju tidaknya suatu masyarakat. Dalam hal ini, sarana penduduk kedua desa dapat di lihat dari tabel 3 berikut:

\section{Tabel 3}

Sarana Penduduk Desa Bangun Saroha

\begin{tabular}{|l|l|l|l|}
\hline No & Prasarana & BANGUN SAROHA & SILAPING \\
\hline 1 & TK & 2 & 2 \\
\hline 2 & SD & 3 & 3 \\
\hline 3 & MDA & 4 & 4 \\
\hline 4 & MTs & - & 2 \\
\hline 5 & MA & - & 2 \\
\hline 6 & Posyandu & 2 & 2 \\
\hline
\end{tabular}

Sumber Data: Buku kedua Desa

\section{d. Keadaan Keagamaan}

Penduduk desa Bangun Saroha Kecamatan Ranto Baek 100\% menganut agama islam. Untuk lebih jelasnya dapat dilihat dari tabel 4 berikut:

\footnotetext{
${ }^{15}$ Profil Desa Bangun Saroha Kecamatan Ranto Baek Kabupaten Mandailing Natal, Tanggal 14 Juli 2018.
} 
Tabel 4

Keadaan Penduduk Menurut Agama DanKepercayaan

\begin{tabular}{|l|l|l|}
\hline No & Agama & Persenrasi \\
\hline 1 & Islam & $100 \%$ \\
\hline 2 & Kristen & - \\
\hline 3 & Budha & - \\
\hline 4 & Hindu & - \\
\hline 5 & Jumlah & $100 \%$ \\
\hline
\end{tabular}

Sumber Data: Papan data kedua Desa

\section{B. Temuan khusus}

\section{Pendidikan Akhlak Ibu Rumah Tangga di Dalam Dalam Merespon Kegiatan Duka Cita Di Desa PerbatasanSumatera Utara Dan Sumatera Barat}

Pendidikan akhlak ibu rumah tangga dalam merespon kegiatan duka cita mencerminkan nilai-nilai akhlak, di mana ibu-ibu rumah tangga dating takziah dengan pakaian yang menutup aurat. Berdasarkan hasil wawancara dengan ibu Marlina sebagai ibu rumah tangga mengatakan bahwa:

"Ibu rumah tangga di luar rumah ketika melihat musibah bersegera menuju lokasi musibah dengan berpakaian seadanya, namun tidak begitu mementingkan penampilan namun sopan dan sesuai dengan ajaran Islam. Dalam hal ini pendidikan akhlak diterapkan ibu-ibu dengan dating takziah dengan pakaian sesuai syariah Islam.”.

Sejalan dengan itu ibu Irawani menyatakan bahwa:

Ibu rumah tangga di luar rumah menjenguk dengan membawa beras pertekong atau uang alakadarnya pada ahli musibah. ${ }^{16}$

Sejalan dengan itu juga ibu Syamsinar sebagai ibu rumah tangga mengatakan bahwa:

Menghadiri kegiatan apasaja yang terjadi di masyarakat yang berkonotasi musibah selalu saja ibu-ibudatang dengan pakaian seadanya tapi menutupi aurat dan selalu saja membawa bantuan sebagai wujud kegotongroyongan dan saling menghargai antara sesama. ${ }^{17}$

\footnotetext{
${ }^{16}$ Irawani, Ibu Rumah Tangga, Wawancara di Desa Bangun Saroha Kecamatan Ranto Baek Kabupaten Mandailing Natal, Tanggal 17 Juli 2018.

${ }^{17}$ Syamsinar, Ibu Rumah Tangga, Wawancara di Desa Bangun Saroha Kecamatan Ranto Baek Kabupaten Mandailing Natal, Tanggal 17 Juli 2018.
} 
Hasil wawancara tersebut membuktikan ibu-ibu rumah tangga menerapkan pendidikan akhlak berperilaku saling menghargai dan saling merasakan bersama duka cita.

Kemudian ibu musdalipah sebagai ibu rumah tangga mengatakan bahwa:

Ibu rumah tangga di luar rumah lebih sering tidak pergi bersama suami ke tempat musibah karena punya waktu yang berbeda dari kesempatan. ${ }^{18}$

Berdasarkan pendapat ibu Ratna sebagai ibu rumah tangga mengatakan bahwa:

Ibu rumah tangga di luar rumah segera pergi ke tempat musibah berpakaian apa adanya sebagai wujud pemberian contoh yang baik kepada anak mereka dan tetangga dan tidak tergantung siapa orangnya yang kena musibah. ${ }^{19}$

Sejalan dengan pendapat ibu Munawaroh sebagai ibu rumah tangga mengatakan bahwa:

Mengetahui kebutuhan anaknya sebagai teman sebaya dengan orang kampung, maka ibunya bersegera mungkin ke tempat musibah dalam rangka suasana yang harmonis. $^{20}$

Sesuai dengan pendapat ibu Ani sebagai ibu rumah tangga mengatakan bahwa:

Ibu rumah tangga yaitu menjaga kehormatan suami, dan menjaga perasaan anak bila mana ada terjadi musibah di masyarakat sebagai wujud kekompakan di tingkat usia anak anak mereka ${ }^{21}$

Najm mengatatan: Ibu rumah tangga di luar rumah segera pergi ke tempat musibah berpakaian apa adanya sebagai wujud pemberian contoh yang baik kepada anak mereka dan tetangga dan tidak tergantung siapa orangnya yang kena musibah, namun mereka juga beramai ramai ikut menyoladkan jenazah kalau ada yang meninggal.

\footnotetext{
${ }^{18}$ Musdalipah, Ibu Rumah Tangga, Wawancara di Desa Bangun Saroha Kecelakukan Ranto Baek Kabupaten Mandailing Natal, Tanggal 18 Juli 2018.

${ }^{19}$ Ratna, Ibu Rumah Tangga di Desa Bangun Saroha Kecamatan Ranto Baek Kabupaten Mandailing Natal, Tanggal 18 Juli 2018.

${ }^{20}$ Munawaroh, Ibu Rumah Tangga, Wawancara di Desa Bangun Saroha Kecamatan Ranto Baek Kabupaten Mandailing Natal, Tanggal 19 Juli 2018.

${ }^{21}$ Ani, Ibu Rumah Tangga, Wawancara di desa Bangun Saroha Kecamatan Ranto Baek Kabupaten Mandailing Natal, Tanggal 19 Juli 2018.
} 


\section{Pendidikan Akhlak Ibu Rumah Tangga di Dalam Dalam Merespon Kegiatan Suka Cita Di Desa PerbatasanSumatera Utara Dan Sumatera Barat}

Pendidikan akhlak yang diterapkan ibu-ibu dalam merespon kegiatan suka cita terlihat pada acara peseta. Di mana masih kuat rasa saling menghormati di mana undangan dengan penuh kekeluargaan.Hal ini membuktikan bahwa pendidikan akhlak dalam perilaku menghormati sesama manusia sangat kuat.

Pendapat ibu Zuraida sebagai ibu rumah tangga mengatakan bahwa:

Meminta izin kepada suami atau anak apabila keluar rumah untuk mengikuti acara pesta (suka cita) sepanjang ada undangan yang bersifat lisan atau tulisan, dan memperlihatkan pakaian yang terbaru yang tersedia di rumah, namun dalam batas batas kesopanan untuk menutup aurat ${ }^{22}$

Kemudian dengan Muhammad Jafar dan S. Lubis sebagai tokoh agama mengatakan bahwa:

Tidak ikut mengatur dan mengelola acara suka cita karena ada petugas khusus yang sudah ditunjuk bersama dalam musyawarah antara pihak punya acara dengan kaum kerabat terdekat, tokoh masyarakat banyak berperan dalam hal kegiatan penyediaan makanan siap saji untuk tamu undangan, dan penyampaian informasi menyeluruh kepada setiap lapisan masyarakat yang datang bahwa acara suka cita adalah sebagai bentuk acara syukuran kepada Sang Khalik yang harus dilestarikan sesuai dengan tuntutan budaya nenek moyang yang bersinergi dengan tuntutan agama. ${ }^{23}$

Sejalan dengan itu Sari dan Tami Sebagai Anak dari ibu rumah tangga mengatakan bahwa:

Memberikan kasih sayang dan perhatian kepada pihak yang punya acara suka cita adalah sesuatu yang mutlak bila mana sudah mendapat undangan lisan mapun tulisan tanpa tidak banyak lagi pertimbangan tentang kesalahan yang punya acara. ${ }^{24}$

${ }^{22}$ Zuraidah, Ibu Rumah Tangga, Wawancara di Desa Bangun Saroha Kecamatan Ranto Baek Kabupaten Mandailing Natal, Tanggal 20 Juli 2018.

${ }^{23}$ Muhammad Jafar, Tokoh Agama, Wawancara di Desa Bangun Saroha Kecamatan Ranto Baek Kabupaten Mandailing Natal, Tanggal 20 Juli 2018.

${ }^{24}$ Sari, Anak Ibu rumah tangga, Wawancara di Desa Bangun Saroha Kecamatan Ranto Baek Kabupaten Mandailing Natal, Tanggal 20 Juli 2018. 
Sesuai dengan hal tersebut Evita Sari dan Tami sebagai anak ibu rumah tangga mengatakan bahwa:

Ibu rumah tangga di luar rumah pergi ke pesta dengan pakaian rapi dan tergolong pakaian yang masih baru bahkan pada Ibu ibu usia produktif mengusahakan adanya pakaian terbaru walaupun dengan jalan pembeliannya dengan cara dicicil, yang demikian ini adalah lambing keberhasilan mengumpul uang dengan cara tidak begitu mengganggu keuangan dapur. ${ }^{25}$

Hasil observasi peneliti pada hari Sabtu 21Juli 2018, Jam 08.00-10.00, di kedua desa, peneliti melihat bahwa ibu rumah tangga yang ada di desa tersebut memiliki akhlak yang baik dalam berpakaian dan berbicara dan selalu waspada dalam memanfaatkan waktu dengan sebaikbaiknya bersama yang punya acara suka cita untuk sampai selesai acaranya. ${ }^{26}$

Lebih lanjut yang berkenaan dengan di atas berdasarkan hasil wawancara dengan ibu Najm dan observasi peneliti di dua desa tapi terutama di desa Silaping: " bila mana ada acara pesta adat maka mereka ibu rumah tanggga usia produktif cenderung suka memakai pakaian terbaru yang dipersiapkan sejak awal dengan cara dicicil”".

\section{Kegiatan ibu rumah tangga dalammengikuti program-program pemerintahan Desa Di}

\section{Desa PerbatasanSumatera Utara Dan Sumatera Barat}

Kegiatan ibu rumah tangga adalah bagian dari program yang dilaksanakan oleh pemerintah adalah mengikuti kegiatan PKK, Memanfaatkan Posyandu, melestarikan budaya daerah yaitu latihan kesenian manortor, silat perempuan, dan menghapal lagu lagu daerah tapanuli.

Wawancara dengan ibu Dahliana mengatakan bahwa:

Ikut beperan aktif dalam kegiatan program pemerintahan, dalam acara pelaksanaan

Ibu PKK melalui tes kesehatan, membuat apotek hidup, dan mengembangkan potensi ibu rumah tangga melalui pelatihan masak-memasak. ${ }^{27}$

Wawancara dengan ibu Mariana sebagai ibu rumah tangga mengatakan bahwa:

\footnotetext{
${ }^{25}$ Evita Sari, Anak Ibu Rumah Tangga, Wawancara di Desa Bangun Saroha Kecamatan Ranto Baek Kabupaten Mandailing Natal, Tanggal 21 Juli 2018.

${ }^{26}$ Observasi Penelitidi Desa Bangun Saroha Kecamatan Ranto Baek Kabupaten Mandailing Natal, pada hari Sabtu, 21 Juli 2018.

${ }^{27}$ Dahliana, Ibu Rumah Tangga, Wawancara, di Desa Bangun Saroha Kecamatan Ranto Baek Kabupaten Mandailing Natal, Tanggal 22 Juli 2018.
} 
Ibu rumah tangga menanam tanaman apotek hidup yang bisa dimanfaatkan sebagai obat-obatan misalnya: jahe, kunyit, lengkuas,serai. ${ }^{28}$

Sejalan dengan itu wawancara dengan kepala desa yang bernama Samhar Lubis mengatakan bahwa:

Kegiatan ibu rumah tangga dalam mengikuti program-program pemerintahan selalu melaksanakan kegiatan mengikuti lomba memasak dalam PKK, membuat apotek hidup dalam lingkungan desa dan juga mengikuti tes kesehatan secara menyeluruh. ${ }^{29}$

Dari hasil wawancara tersebut membuktikan bahwa kegiatan ibu rumah tangga dalammengikuti program-program pemerintahan desa di desa PerbatasanSumatera Utara Dan Sumatera Barat ditemukan bahwa ibu-ibu menrapkan pendidikan akhlak.Pendidkan akhlak yang diterapkan ibu-ibu adalah saling memupuk rasa persaudaraan, berlomba-lomba berbuat baik demi kemajuan desa.

Kemudian wawancara dengan Muhammad Jafar dari Bangun Saroha dan S.Lubis sebagai tokoh agama dan adat mengatakan bahwa:

Kegiatan ibu rumah tangga dalam mengikuti program-program pemerintahan desa Bangun Saroha salah satunya ibu rumah tangga melaksanakan pengajian rutin setiap hari Senin, pemeriksaan kesahatan di posyandu, membuat apotek hidup dan pelatihan masakmemasak, kalau di desa silaping juga kegiatan yang sama dan mensukseskan Peringatan Hari Besar Kebangsaan. ${ }^{30}$

Sejalan dengan Nur hidayah sebagai anak ibu rumah tangga mengatakan bahwa:

Kegiatan-kegiatan ibu rumah tangga yang dilaksanakan di desa Bangun Saroha antara lain mengikuti lomba memasak dalam PKK, dan di desa silaping yang dikatakan oleh Najm sangat antusias mengikuti Peringatan Hari Besar Kebangsaan ${ }^{31}$

Hasil observasi peneliti di desa pada hari,Selasa 24 Juli 2018 bahwa peneliti melihat kegiatan-kegiatan pemerintahan Desa dimana keseluruhan ibu rumah tangga sudah berperan aktif dalam kegiatan tersebut. ${ }^{32}$

\footnotetext{
${ }^{28}$ Mariana , Ibu Rumah Tangga, Wawancara di Desa Bangun Saroha Kecamatan Ranto Baek Kabpaten Mandailing Natal, Tanggal Ibu Rumah Tanggal 22 Juli 2018.

${ }^{29}$ Samhar Lubis, Kepala Desa, Wawancara, di Desa Bangun Saroha Kecamatan Ranto Baek Kabupaten Mandailing Natal, Tanggal 23 Juli 2018.

${ }^{30}$ Muhammah Jafar,Tokoh Agama, Wawancara di Desa Bangun Saroha Kecamatan Ranto Baek Kabupaten Mandailing Natal, Tanggal 23 Juli 2018.

${ }^{31}$ Nur Hidayah, Anak Ibu Rumah Tangga, Wawancara di Desa Bangun Saroha Kecamatan Ranto Baek Kabupaten Mandailing Natal, Tanggal 23 Juli 2018.
} 
Dari hasil observasi dan wawancara di desa dapat disimpulkan bahwa kegiatan program pemerintahan desa sudah diterapkan dan sudah menjadi tradisi di desa tersebut.

\section{Aktivitas ibu rumah tangga dalam mengikuti program pendidikanakhlak di desa PerbatasanSumatera Utara dan Sumatera Bara}

Berdasarkan hasil wawancara dengan ibu Aisyah sebagai ibu rumah tangga mengatakan bahwa:

Pembinaan akhlak dengan membiasakan anak untuk mengucapkan salam ketika keluar dan masuk rumah, ibu rumah tangga juga mengajak anak untuk shalat berjamaah, membiasakan menghargai waktu dan tidak melakukan aktivitas yang tidak bermanfaat. $^{33}$

Kemudian berdasarkan hasil wawancara dengan ibu Darismasebagai ibu rumah tangga mengatakan bahwa:

Memberi pendidikan agama misalnya: menyekolahkan anaknya di Pesantren atau Aliyah. Membina hubungan dekat dengan anak apabila anak ada masalah ibu rumah tangga harus mau mendengarkan apa yang diceritakan anaknya dan harus memberi kesempatan kepada anak untuk bersosialisasi dengan lingkungan seperti teman sekolah, memiliki sahabat dan bergaul. ${ }^{34}$

Sejalan dengan itu juga Enismaniarsebagai ibu rumah tangga di desa mengatakan bahwa:

Memberikan kepercayaan dan tanggung jawab misalnya membiarkan mereka memilih hobi yang mereka sukai selagi bersifat positif dan membiasakan anak berkata lemah lembut. ${ }^{35}$

Kemudian dengan ibu Dewi sebagai ibu rumah tangga mengatakan bahwa:

Dengan cara menjaga dan memelihara anak menjelang dewasa, mengembangkan seluruh potensi dan membina kepribadian anak. ${ }^{36}$

\footnotetext{
${ }^{32}$ Observasi Peneliti, di Desa Bangun Saroha Kecamatan Ranto Baek Kabupaten Mandailing Natal, pada hari Selasa, 24 Juli 2018.

${ }^{33}$ Aisyah, Ibu Rumah Tangga, Wawancara di Desa Bangun Saroha Kecamatan Ranto Baek Kabupaten Mandailing Natal, Tanggal 25 Juli 2018.

${ }^{34}$ Darisma, Ibu Rumah Tangga, Wawancara di Desa Bangun Saroha Kecamatan Ranto Baek Kabupaten Mandailing Natal, Tanggal 25 Juli 2018.

${ }^{35}$ Enismaniar, Ibu Rumah Tangga, Wawancara di Desa Bangun Saroha Kecamatan Ranto Baek Kabupaten Mandailing Natal, Tanggal 25 Juli 2018.

${ }^{36}$ Dewi, Ibu Rumah Tangga, Wawancara di Desa Bangun Saroha Kecamatan Ranto Baek Kabupaten Mandailing Natal, Tanggal 26 Juli 2018.
} 
Sesuai dengan hal tersebut Novita sebagai anak ibu rumah tangga mengatakan bahwa:

Menjadi contoh yang baik dalam hal bergaul contohnya mengatur waktu anak antara belajar dan bermain, membiasakan anak untuk menabung. ${ }^{37}$

Hasil observasi peneliti pada hari Kamis 26 Juli 2018 di sekitar kampung baik Bangun Saroha maupun desa Silaping bahwa peran ibu rumah memberikan pendidikan akhlak dan agama melalui Taman Pendidikan Alqur'an. ${ }^{38}$

Berdasarkan hasil wawancara dan observasi peneliti di desa dapat disimpulkan bahwa peran ibu rumah tangga dalam membina akhlak anak remaja memang benar menerapkan pembiasaan mengucapkan salam ketika masuk dan keluar rumah.

\section{Analisis Hasil Penelitian}

Berdasarkan analisis hasil penelitian oleh peneliti bahwa pendidikan akhlak ibu rumah tangga memiliki sifat kepedulian terhadap situasi yang menonjol di masyarakat hal ini dapat dilihat dari pemberian nasehat, partisipasi aktif keseharian di dalam mengurus masyarakat yang kena musibah, dan memoles kegiatan acara pesta adat sampai selesai, serta selalu memanfaatkan ipen kegiatan-kegiatan dalam mengikuti program pemerintahan di dua desa berupa pelaksanaan PKK, posyandu, dan rumah kreatif untuk mengembangan potensi ibu rumah tangga dalam peningkatan incam rumah tangga.

Peran ibu rumah tangga dinilai sangat baik dalam membina akhlak anak remaja dengan membiasakan perilaku yang terpuji salah satunya dengan membiasakan pengucapan salam pada waktu masuk dan keluar rumah serta ibu ibu rumah tangga tersebut mengontrol rapor anak mereka yang dikeluarkan oleh Taman Pendidikan Alqur'an, serta mengontrol anak mereka untuk berkata baik dalam bergaul di kalangan perguruan dan masyarakat yang lebih luas.

\section{Keterbatasan Penelitian}

Penelitian yang dilaksanakan di dua desa ini adalah dengan memanfaatkan sumbangan lembaga sosial yang ada di desa, belum sempat meneliti informan informan yang ada di desa tetangga yang berkarakter sama.

\footnotetext{
${ }^{37}$ Novita, Anak Ibu Rumah Tangga, Wawancara di Desa Bangun Saroha Kecamatan Ranto Baek Kabupaten Mandailing Natal, Tanggal 26 Juli 2018.

${ }^{38}$ Observasi Penelitidi Desa Bangun Saroha Kecamatan Ranto Baek Kabupaten Mandailing Natal, Tanggal 26Juli 2018.
} 


\section{KESIMPULAN}

Dari temuan temuan yang diperoleh di lapangan, maka dapat disimpulkan sebagai berikut:

a. Pendidikan akhlak ibu rumah tangga kegiatan duka cita di dua desa Bangun Saroha dan Silaping, yaitu: waspada dalam memanfaatkan waktu dalam keseharian bila mana ada acara musibah di masyarakat, berpakaian sopan apa adanya tanpa membuka aurat dan mereka itu memperlihatkan tutur kata, serta sangat peduli menjaga kebersamaan kampung.

b. Berpenampilan sangat baik terutama berpakaian ikut berpartisipasi aktif sampai acara adat selesai.

c. Mengikuti dengan serius program kegiatan pemerintah desa berupa PKK, Posyandu, Gotong royong desa, mengikuti acara acara ritual pemerintah seperti upacara hari hari besar kebangsaan.

d. Dalam upaya pembinaan akhlak anak anak dari Ibu Rumah Tangga di dua desa terutama menyekolahkan anak mereka pada Taman Pendidikan Alqur'an .

\section{DAFTAR KEPUSTAKAAN}

Abd. Rachman Assegaf, Aliran Pemikiran Pendidikan Islam : Hadharah Keilmuan Tokoh Klasik Sampai Modern Jakarta: Rajawali Pers, 2013.

Abdul Hafizh Nur Muhammad, Mendidik Anak Bersama Rasul, Cet.1, Bandung: Al-Bayan, 1997.

Abdullah, Kamus Besar Bahasa Indonesia, Jakarta: Sandro Jaya, Th.

AbuddinNata, Metodologi Studi Islam, Jakarta: PT. Raja GrapindoPersada, 2002.

Ahmad Nizar Rangkuti, Metode Penelitian Pendidikan Pendekatan Kuantiatif, Kualitatif, Ptk, dan Penelitian Pengembangan, Bandung: Cita pustaka Media, 2016.

Chabib Thoha, dkk, Metodologi Pengajaran Agama,Semarang: Pustaka Pelajar, 2004.

Departemen Agama RI, al-Qur'an dan Terjemahannya, Bandung: Diponegoro, 2007

Erwin Yudi Prahara, Jurnal Kependidikan dan Kemasyarakat "Konsep Akhlak Menurut Alghazali", dalam Jurnal Cendikiawan, Volume.3 No. 1, Januari 2005.

Hamdani Ihsan dkk, Filsafat Pendidikan Islam, Bandung: Pustaka Setia, 2007. 
Hery Noer Aly, Ilmu Pendidikan Islam, Jakarta: Logos, 1999.

Tim Pengembangan Ilmu Pendidikan, Ilmudan Aplikasi Pendidikan Bagian IV, Bandung: Imperial Bhakti Utama, (Imtima), 2007.

Imam Abu Husein Muslim bin Hajjaj Al-QusyairyAnNaisabury,TerjemahanShahih Muslim, Juz IV, KH. Adib Bisri MUsthafa, Semarang: CV AsySyifa', 1993.

LexyJ.Moleong, Metodologi Penelitian Kualitatif, Bandung: Rosdakarya, 2000.

Lies Afrianti Hasibuan, Motivasi Ibu-ibu Rumah Tangga Untuk Mengikuti Kegiatan Majelis Taklim Di Pondok Pesantren Musthafawiyah Purba Baru Kecamatan Lembah Sorik Merapi, (Skripsi IAIN Padangsidimpuan), 2015.

M. Yatim Abdullah, Studi Akhlak Dalam Perspektif Al-Qur'an, Jakarta: Amzah, 2007.

Quraish Shihab, Lentera Hati Kisah dan Hikmah Kehidupan, Bandung: Mizan, 1994.

RusmanHasibuan, Inilah Islam, Padangsidimpuan: Pencetakan Ilmiyah, 2000.

Sukardi, Metodologi Penelitian Pendidikan Kompetensi dan Prakteknya, Jakarta: BumiAksara, 2003.

Sunaryo, Pengantar Umun Pendidikan, (Jakarta: Aksara Baru, 1985), hlm. 117.

Syafaruddin dkk, IlmuPendidikan Islam, Jakarta: Hijri PustakaUtama, 2006

Tim Pengembangan IlmuPendidikan, Ilmudan Aplikasi Pendidikan Bagian III Pendidikan Disiplin Ilmu, Bandung: Imperial Bhakti Utama (IMTIMA), 2007.

Yunahar Ilyas, Kuliah Akhlak, Yogyakarta: Pustaka Pelajar Offset, 1999.

Zakiah Darajat, dkk, Ilmu Pendidikan Islam Jakarta: PT Bumi Aksara, 2008. 